\title{
Environmental Stability and Correlation of Soybean Seed Starch with Protein and Oil Contents
}

\author{
Sanjeev K. Dhungana ${ }^{1}$, Krishnanand P. Kulkami ${ }^{1}$, Minsu Kim ${ }^{1}$, Bo-Keun $\mathrm{Ha}^{2}$, Sungtaeg Kang ${ }^{3}$, Jong Tae Song ${ }^{1}$, \\ Dong-Hyun Shin', Jeong-Dong Lee ${ }^{1,4 *}$ \\ ${ }^{1}$ School of Applied Biosciences, Kyungpook National University, Daegu 41566, Korea \\ ${ }^{2}$ Division of Plant Biotechnology, College of Agriculture and Life Science, Chonnam National University, Gwangju 61186, Korea \\ ${ }^{3}$ Department of Crop Science and Biotechnology, Dankook University, Cheonan 31116, Korea \\ ${ }^{4}$ Institute of Agricultural Science \& Technology, Kyungpook National University, Daegu 41566, Korea
}

\begin{abstract}
Seed starch content (SSC) is a decisive factor influencing soy food quality. Variation in SSC affects the composition of major components, oil, and protein in soybean seeds. Therefore, understanding $\mathrm{G} \times \mathrm{E}$ interaction of SSC is important to produce soybeans with stable SSC. In the present study, $\mathrm{G} \times \mathrm{E}$ interactions of 17 soybean genotypes having different SSC (0.24-1.48\%) and correlation of SSC with crude protein (CP) and crude fat (CF) were investigated. The genotypes were evaluated for SSC and other traits at two planting dates across three locations over two years (2015 and 2016). The genotype $\times$ year, genotype $\times$ location, and genotype $\times$ year $\times$ location interactions were found to be significant $(P \leq 0.001)$ for SSC, CP, and CF. The average SSC content was found to be higher in 2015 than in 2016. Late planted soybeans contained higher SSC than the early planting soybeans. The SSC was negatively affected by the average daily mean and minimum temperatures and cloudiness during the pod-filling stage. Based on the mean rank, IT189276 (1.39\%) was observed to be the most stable genotype among the high starch containing soybeans. Significant $(P \leq 0.0001)$ negative correlations were found between SSC and CP as well as CP and CF contents. However, a significant $(P \leq 0.05)$ positive correlation was observed between SSC and CF content. Results of this study showed that SSC affects the seed protein and oil contents and is significantly influenced by the growing environments.
\end{abstract}

Keywords Soybean, Seed starch content, Crude fat, Crude protein, Environmental stability

\section{INTRODUCTION}

Soybean [Glycine max (L.) Merr.] is an important legume crop in the world, domesticated mainly for its high oil and protein contents (Patil et al. 2017). Major constituents of soybean seeds are protein $(\sim 40 \%)$, carbohydrate $(\sim 34 \%)$, oil ( $\sim 21 \%)$, and ash ( 5\%) (Burton 1997). Carbohydrate is an important component of the soybean seeds. A large proportion of the carbohydrates in soybean seeds are insoluble polysaccharides, including pectin, cellulose, hemicellulose, and starch (Liu 1997). Soluble carbohydrates are comprised of monosaccharides (glucose and fructose), disaccharides (sucrose), and oligosaccharides (raffinose and stachyose) (Liu 1997). Soybean seeds contain 9-12\% total soluble carbohydrates, which include 4-5\% sucrose, $1-2 \%$ raffinose, and 3.5-4.5\% stachyose (Greiner 1990). The insoluble polysaccharides include $20-30 \%$ non-starch polysaccharides (Choct 1997) and 1\% starch (Wilson et al. 1978).

Starch, upon cooking, is converted into maltose, which adds sweetness to the vegetable soybeans (Masuda 2004). It also adds additional softness to the food after boiling (Jeong et al. 2010). Hence, high starch containing soybeans are preferred to make high-quality soy foods, such as boiled

Received September 22, 2017; Revised November 6, 2017; Accepted November 8, 2017; Published December 1, 2017

*Corresponding author Jeong-Dong Lee, jdlee@knu.ac.kr, Tel: +82-53-950-5709, Fax: +82-53-958-6880 
soybean and fermented soybean paste. The starch in soybean seeds has been found to enhance tryptic digestion of some of the protein fractions (Boonvisut and Whitaker 1976). Resistant starch from soybean seeds has been used in producing nanoparticles, which can be used as potential encapsulating material in the colon-specific delivery of bioactive compounds such as drugs and nutrients (Sivapragasam et al. 2014). An inverse relationship between the seed starch content (SSC) and protein content has been observed in Korean soybean germplasm (Koo et al. 2014). Besides, a significant correlation between fatty acid composition and amylose, one of the two components (amylose and amylopectin) of starch, has been reported (Stevenson et al. 2006).

The genetic composition of the plant (genotype, G), the environment $(E)$, and the $G \times E$ interaction influence the plant growth and development (Ei-Soda 2014). To develop the cultivars with stable trait expression across environments, G x E interactions need to be accounted in breeding programs. The plant's response in particular environment needs to be understood in terms of underlying QTL and their allelic composition. Earlier, we identified several loci controlling SSC in soybean (Dhungana et al. 2017) and observed that majority of the QTL for SSC were found to be significantly influenced by the growing environment. Such effects have been observed for other complex traits like forage quality (Asekova et al. 2016), isoflavone content (Primomo et al. 2005), seed weight (Kulkarni et al. 2016, 2017), seed protein (Panthee et al. 2005), fatty acid composition, oil and protein contents (Rennie and Tanner 1989; Dornbos and Mullen 1992; Primomo et al. 2002; Fehr et al. 2003; Hou et al. 2006; Oliva et al. 2006; Dhakal et al. 2013; Asekova et al. 2014), and yield (Rao et al. 2002; Shen et al. 2006) in soybean.

A large number of studies have been carried out in recent past to estimate the amount of $\mathrm{G} \times \mathrm{E}$ interaction for carbohydrate components in soybean. The environmental stability study of seed carbohydrates in soybean lines containing wild-type or variant alleles of raffinose synthase 2 showed variation in carbohydrates composition across spatial and temporal environments (Bilyeu and Wiebold 2016). The authors observed a significant effect of location on the concentration of sucrose, but no such effects were observed on raffinose and stachyose concentrations. In another study by Kumar et al. (2010), the genotype $\times$ location interaction was found to be significant for sucrose, raffinose, and stachyose contents in soybean. Converse to these results, Cicek (2001) observed that $\mathrm{G} \times \mathrm{E}$ interaction was significant for agronomic traits like maturity, plant height, canopy spread, yield, seed size, leaf length, and leaf width but was not significant for seed sucrose, stachyose, or raffinose contents. Likewise, Geater and Fehr (2000) also observed that the cultivar $\times$ location interaction was not significant for total sugar content. Cober et al. (1997) observed that $\mathrm{G} \times \mathrm{E}$ interaction effects for seed sugar levels were significant for year, but not significant for location. Additionally, they observed significant year $\times$ location and $\mathrm{G} \times \mathrm{E}$ interactions for the sugar levels. These studies indicate that the growing environment show variable effects on the carbohydrate components in soybean.

The $\mathrm{G} \times \mathrm{E}$ interaction effects on starch properties have been studied in plants other than soybean. Bach et al. (2013) studied genotype, year, and location effects on starch digestibility components in potato. They did not find significant $\mathrm{G} \times \mathrm{E}$ interaction, however, most of the variations in the components were due to environmental effects, especially location $\times$ year interactions. Significant interactions between genotypes, locations, and harvest period were observed in cassava starch yield (Mtunguja et al. 2016).

$\mathrm{SSC}$ is a quantitative trait, controlled by multiple loci and influenced by the growing environment. SSC in soybean is reported to influence soy food quality as well as protein and fat contents in seeds. Since the variation in seed constituents is affected by genetic and environmental (temporal and spatial) factors, and their interactions, understanding the $\mathrm{G} \times \mathrm{E}$ interaction of soybean SSC is of great importance. To date, no studies of $\mathrm{G} \times \mathrm{E}$ interaction for SSC in soybean have been reported. The objectives of the present study were to investigate the environmental stability of SSC, and its relationship with crude protein (CP) and crude fat (CF) contents in soybean seeds. 


\section{MATERIALS AND METHODS}

\section{Plant materials and cultivation}

We screened more than 1,064 black soybean lines for high, medium, and low starch contents in their seeds. The initial screening was carried out using a rapid iodine test (Jeong et al. 2010). We identified 90 lines showing variation for starch content based on the iodine test. The SSC of the identified 90 lines was measured using a total starch assay kit (Megazyme International Ireland Ltd., Wicklow, Ireland) following an approved method 76-13.01 (AACC 2010) as reported in Dhungana et al. (2017).

Three groups of soybean genotypes, each having 5 high-
( $>1.75 \%), 5$ medium- $(0.75-1.5 \%)$, and 5 low- $(<0.5 \%)$ starch contents were randomly selected from the 90 lines. In addition, two cultivated soybeans, Pungsannamul (Suh et al. 1997) and Williams 82, were used as checks. Together, a total of 17 soybean genotypes were used in this study (Table 1).

The SSC of these genotypes was evaluated in two planting dates at three locations: Gunwi, Gwangju, and Cheonan in the Republic of Korea in 2015 and 2016. Geolocation information and dates of planting at each location and year are given in Table 2. The experiments were performed in a randomized complete block design with two replications at each test. Seeds were sown in hill

Table 1. Description of 17 soybean genotypes, mean starch, crude protein and crude fat contents and starch group of each grownin 11 environments to evaluate the stability of seed starch content.

\begin{tabular}{llccc}
\hline \hline Genotype & \multicolumn{1}{c}{ Starch group } & $\begin{array}{c}\text { Mean starch } \\
\text { content }(\%)\end{array}$ & $\begin{array}{c}\text { Mean crude fat } \\
\text { content }(\%)\end{array}$ & $\begin{array}{c}\text { Mean crude protein } \\
\text { content }(\%)\end{array}$ \\
\hline IT25334 & High starch line & 1.34 & 23.4 & 40.8 \\
IT141778 & High starch line & 1.26 & 19.3 & 39.4 \\
IT177744 & High starch line & 1.02 & 21.5 & 42.0 \\
IT183905 & High starch line & 1.48 & 18.9 & 42.1 \\
IT189276 & High starch line & 1.39 & 22.1 & 41.5 \\
IT25344 & Medium starch line & 0.66 & 22.3 & 43.7 \\
IT115763 & Medium starch line & 0.75 & 22.1 & 43.2 \\
IT143112 & Medium starch line & 0.80 & 23.4 & 42.6 \\
IT177234 & Medium starch line & 0.85 & 21.9 & 43.2 \\
IT189205 & Medium starch line & 0.99 & 22.8 & 43.0 \\
IT228277 & Low starch line & 0.24 & 21.9 & 45.7 \\
IT228577 & Low starch line & 0.25 & 24.9 & 42.7 \\
IT228620 & Low starch line & 0.35 & 22.4 & 43.9 \\
IT229949 & Low starch line & 0.41 & 22.2 & 44.4 \\
IT230194 & Low starch line & 0.41 & 22.1 & 44.0 \\
Pungsannamul & Check & 0.64 & 16.8 & 42.0 \\
Williams 82 & Check & 0.50 & 20.9 & 40.1 \\
\hline
\end{tabular}

Table 2. Geolocation information and planting dates (environments) at three locations in 2015 and 2016.

\begin{tabular}{|c|c|c|c|c|c|c|c|c|}
\hline \multirow{3}{*}{ Location } & \multirow{3}{*}{$\begin{array}{l}\text { Geographic } \\
\text { coordinates }\end{array}$} & \multicolumn{7}{|c|}{ Planting date ${ }^{\mathrm{z})}$} \\
\hline & & \multicolumn{3}{|c|}{2015} & \multicolumn{4}{|c|}{2016} \\
\hline & & Date1 & \multicolumn{2}{|r|}{ Date2 } & \multicolumn{2}{|r|}{ Date1 } & \multicolumn{2}{|r|}{ Date2 } \\
\hline Gunwi & $36^{\circ} 07^{\prime} \mathrm{N}, 128^{\circ} 38^{\prime} \mathrm{E}$ & 30 May (E1) & 20 & June (E2) & 29 & May (E7) & & $\mathrm{NA}^{\mathrm{y})}$ \\
\hline Gwangju & $35^{\circ} 10^{\prime} \mathrm{N}, 126^{\circ} 54^{\prime} \mathrm{E}$ & 2 June (E3) & 25 & June (E4) & 29 & May (E8) & 23 & June (E9) \\
\hline Cheonan & $36^{\circ} 49^{\prime} \mathrm{N}, 127^{\circ} 10^{\prime} \mathrm{E}$ & 2 June (E5) & 30 & June (E6) & 2 & June (E10) & 29 & June (E11) \\
\hline
\end{tabular}

${ }^{\mathrm{z})}$ Letter and number in parenthesis for each planting date in various years are designated as environments.

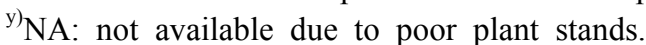


plots with 10 seeds per hill with $70 \mathrm{~cm}$ between rows and 50 $\mathrm{cm}$ between hills. Each hill was considered as a plot. A similar multi-environmental trial for fatty acid stability was conducted in an earlier study in hill plots with two replications (Chae et al. 2015). The plants were harvested at maturity and dried seeds were used to analyze the seed starch, $\mathrm{CP}$, and $\mathrm{CF}$ contents.

\section{Starch analysis}

SSC was measured using a total starch assay kit (Megazyme International Ireland Ltd., Wicklow, Ireland) following an approved method 76-13.01 (AACC 2010), as reported in Dhungana et al. (2017). Starch content was determined using the following equation,

$$
\text { Starch }(\%)=\Delta_{A} \times F / W \times F V \times 0.9
$$

where,

$\Delta_{A}=$ Absorbance read against the reagent blank

$F=100(\mu \mathrm{g}$ of D-glucose)/absorbance for $100 \mu \mathrm{g}$ of glucose

$W=$ Weight in milligrams of the flour analyzed

$F V=$ Final volume

$0.9=$ Adjustment from free D-glucose to anhydro D-glucose (as occurs in starch)

\section{Crude fat and crude protein analyses}

Soybean seeds were ground into powder using a commercial mixture (SFM-555SP, Shinil, Seoul, Korea) and scanned using XDS-NIRS rapid content analyzer (FOSS Analytical, Slangerupgade, Denmark) to calculate reflectance spectra. The spectra were examined using the equations which were previously developed (Chung et al. 2001) based on the spectra from standard samples, calibration, and validation assessments.

\section{Meteorological data collection}

Data for the average daily weather conditions (daily mean, daily maximum and daily minimum temperatures, and daily cloudiness) during the pod-filling period (September and October) at three locations (Gunwi, Gwangju, and Cheonan, Republic of Korea) in 2015 and 2016 were collected from the Meteorological stations located within $30 \mathrm{~km}$ from the soybean fields.

\section{Statistical analysis}

Analysis of variance (ANOVA) for SSC, $\mathrm{CP}$, and $\mathrm{CF}$ was calculated using the PROC MIXED of SAS (SAS Institute 2013). All sources of variances were considered random as mentioned in Kulkarni et al. (2017). The difference among the means was compared using least significant difference (LSD) at 0.05 probability using SAS (SAS Institute 2013).

Broad-sense heritability $\left(H^{2}\right)$ for SSC was calculated as $H^{2}=\sigma_{\mathrm{G}}^{2} /\left(\sigma_{\mathrm{G}}^{2}+\sigma_{\mathrm{GE}}^{2} / E+\sigma^{2} \mathrm{e} / r E\right)$ where $E, G$, and $r$ are the number of environments, genotypes, and replications, respectively (Toker 2004). $\sigma_{G}^{2}$ and $\sigma^{2}$ e are components of variance for genotype and error, respectively.

Stability of genotypes for SSC across environments was determined by mean, range, the coefficient of variation (CV), and stability coefficient ( $b_{E}$ ) (Lee et al. 2009). b $b_{E}$ was calculated from the regression of the mean SSC of genotype at an environment on an environmental index. The environmental index was calculated from the mean SSC of all the genotypes at an environment minus the mean SSC of all the genotypes averaged across 11 environments (Lee et al. 2009). Genotypes having stability coefficients (b-value) close to zero were considered as more stable, whereas those deviate considerably from zero (either positive or negative) were considered as less stable across the environments. The PROC REG of SAS (SAS Institute 2013) package was used to calculate the slopes. The correlations among SSC, CF, and $\mathrm{CP}$ in seeds were analyzed using the PROC CORR of SAS (SAS Institute 2013).

\section{RESULTS}

\section{Variation in seed starch, crude protein, and crude fat contents}

The SSC, CP, and CF of 17 soybean genotypes were evaluated in two planting dates at three locations over two years. Crude protein and CF contents of seeds of the 15 soybean lines ranged from $39.4-45.7 \%$ and $18.9-24.9 \%$, respectively; whereas those of the check were $40.1-42.0 \%$ and $16.8-20.9 \%$ (Table 1), respectively. There was a significant difference for SSC in years, genotypes, 
Table 3. Analysis of variance for seed starch, crude protein, and crude fat contents of 17 soybean genotypes grown at two planting dates at three locations over two years.

\begin{tabular}{|c|c|c|c|c|c|c|c|c|c|}
\hline \multirow{2}{*}{ Source of variation } & \multicolumn{3}{|c|}{ Starch } & \multicolumn{3}{|c|}{ Crude protein } & \multicolumn{3}{|c|}{ Crude fat } \\
\hline & $\mathrm{df}^{\mathrm{z})}$ & $\mathrm{F}$ value & $\operatorname{Pr}$ & df & $\mathrm{F}$ value & $\operatorname{Pr}$ & df & $\mathrm{F}$ value & $\operatorname{Pr}$ \\
\hline Year & 1 & 136.12 & $<.0001$ & 1 & 696.53 & $<.0001$ & 1 & 6018.34 & $<.0001$ \\
\hline Location & 2 & 107.52 & 0.0092 & 2 & 136.16 & 0.0073 & 2 & 0.62 & 0.6166 \\
\hline Genotype & 16 & 64.02 & $<.0001$ & 16 & 68.44 & $<.0001$ & 16 & 97.59 & $<.0001$ \\
\hline Date & 1 & 18.33 & $<.0001$ & 1 & 0.19 & 0.6606 & 1 & 0.15 & 0.6986 \\
\hline Replication & 1 & 0.1 & 0.7806 & 1 & 0.77 & 0.4717 & 1 & 0.01 & 0.9225 \\
\hline Year $\times$ genotype & 16 & 6.92 & $<.0001$ & 16 & 16 & $<.0001$ & 16 & 42.94 & $<.0001$ \\
\hline Year $\times$ location & 2 & 14.18 & $<.0001$ & 2 & 2.15 & 0.1192 & 2 & 58.95 & $<.0001$ \\
\hline Location $\times$ genotype & 32 & 3.98 & $<.0001$ & 32 & 2.89 & $<.0001$ & 32 & 2.53 & $<.0001$ \\
\hline Genotype $\times$ date & 16 & 3.03 & 0.0001 & 16 & 1.44 & 0.1274 & 16 & 1.26 & 0.2256 \\
\hline Year $\times$ location $\times$ genotype & 32 & 2.17 & 0.0006 & 29 & 3.15 & $<.0001$ & 29 & 2.18 & 0.001 \\
\hline Total & 332 & & & 307 & & & 307 & & \\
\hline
\end{tabular}

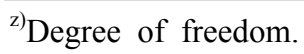

locations, planting dates, and their interactions (Table 3). Late planted (0.88\%) soybeans had higher SSC than those grown at early planting $(0.71 \%)$ dates. The average SSC of the 17 genotypes in $2015(0.93 \%)$ was higher than that in 2016 (0.60\%) (Supplementary Table S1).

Broad-sense heritability $\left(H^{2}\right)$ for SSC was consistent (95.5-96.6\%) over the two years (Supplementary Table S1). The consistent high $H^{2}$ values ( $>95 \%$ ) over two years indicated that a high proportion of phenotypic variance in $\mathrm{SSC}$ was a result of genetic effects.

\section{Stability of seed starch content}

The range, $\mathrm{CV}$, and $\mathrm{b}_{\mathrm{E}}$ for mean $\mathrm{SSC}$ were calculated to evaluate the stability of soybean genotypes in each seed starch category (high, medium, and low) including checks (Table 4). Among the five genotypes in the high seed starch group, IT177744 had the lowest (1.87\%) and IT183905 had the highest $(2.27 \%)$ ranges for SSC. IT189276 had the lowest (36.6\%) and IT177744 had the highest (53.0\%) CV. In the medium seed starch group, IT177234 had the lowest range SSC (1.01\%) and CV (34.4\%) followed by IT143112 and IT25344. The range of SSC for IT229949 was the highest $(0.58 \%)$, whereas that for IT228577 was the lowest (0.18\%). The IT228620 had the lowest CV (14.8\%) among the five genotypes of the low seed starch group. Between the two checks, Pungsannamul ranked higher for range (0.57\%) and CV (23.64\%) than Williams 82.
The stability coefficient $\left(b_{E}\right)$ among the high, medium, and low-seed starch categories, and check genotypes ranged from 1.55-2.44, 0.83-1.51, 0.003-0.35, and 0.310.49 , respectively. Based on the $b_{\mathrm{E}}$ values, IT141778 and IT183905; IT177234 and IT115763; and IT228620 and IT229949 were found to be the most stable and the most unstable genotypes for high, medium, and low seed-starch groups, respectively. From the checks, Williams 82 was found to be more stable (lower $b_{E}$ value) than Pungsannamul.

Mean rank was estimated based on the average values of three stability parameters: range, $\mathrm{CV}$, and $\mathrm{b}_{\mathrm{E}}$ (Table 4). Based on the mean rank, IT189276 was the most stable genotype in the high seed starch group. Similarly, IT177234, IT228620, and Pungsannamul were the most stable genotypes for medium and low seed starch groups and check, respectively. The overall pattern of the stability results from this study showed that the high starch soybean genotypes were less stable than medium or low seed starch genotypes across environments.

\section{Comelation analysis of seed starch, crude protein, and crude fat contents}

Pearson's correlation coefficients for SSC, CP, and CF showed a significant negative correlation between $\mathrm{SSC}$ and $\mathrm{CP}$ as well as $\mathrm{CP}$ and $\mathrm{CF}$, and a significant positive correlation between SSC and CF (Table 5). 
Table 4. Stability parameters range, thecoefficientof variation $(\mathrm{CV})$, stability coefficient $\left(\mathrm{b}_{\mathrm{E}}\right)$, and stability coefficient of determination $\left(r^{2}\right)$ for mean seed starch content of 17 soybean genotypes calculated from 11 environments to evaluate the stability of seed starch among high, medium, and low starch genotypes.

\begin{tabular}{|c|c|c|c|c|c|c|c|c|}
\hline \multirow{2}{*}{$\begin{array}{l}\text { Starch } \\
\text { Group }\end{array}$} & \multirow{2}{*}{ Genotype } & \multirow{2}{*}{$\begin{array}{l}\text { Mean } \\
(\%)\end{array}$} & \multirow{2}{*}{$\begin{array}{c}\text { Range } \\
(\%)\end{array}$} & \multirow{2}{*}{$\begin{array}{l}\text { CV } \\
(\%)\end{array}$} & \multicolumn{3}{|c|}{ Stability coefficients } & \multirow{2}{*}{$\begin{array}{l}\text { Mean } \\
\text { rank }^{\text {y) }}\end{array}$} \\
\hline & & & & & $\mathrm{b}_{\mathrm{E}}^{2)}$ & $P$ & $r^{2}$ & \\
\hline \multirow[t]{5}{*}{ High } & IT25334 & 1.34 & 1.94 & 48.15 & 2.32 & $<.0001$ & 0.89 & 15 \\
\hline & IT141778 & 1.26 & 2.06 & 41.84 & 1.55 & 0.036 & 0.49 & 13 \\
\hline & IT177744 & 1.02 & 1.87 & 53.01 & 1.94 & $<.0001$ & 0.85 & 16 \\
\hline & IT183905 & 1.48 & 2.27 & 48.80 & 2.44 & 0.001 & 0.71 & 17 \\
\hline & IT189276 & 1.39 & 2.11 & 36.58 & 1.74 & $<.0001$ & 0.89 & 12 \\
\hline Mean & & 1.30 & 2.05 & 45.68 & 2.00 & & 0.77 & \\
\hline \multirow[t]{5}{*}{ Medium } & IT25344 & 0.66 & 1.04 & 42.83 & 1.00 & 0.0002 & 0.80 & 10 \\
\hline & IT115763 & 0.75 & 1.26 & 57.28 & 1.51 & $<.0001$ & 0.94 & 14 \\
\hline & IT143112 & 0.80 & 1.04 & 38.59 & 0.99 & 0.0002 & 0.84 & 9 \\
\hline & IT177234 & 0.85 & 1.01 & 34.36 & 0.83 & 0.0049 & 0.60 & 8 \\
\hline & IT189205 & 0.99 & 1.49 & 47.08 & 1.49 & 0.0028 & 0.69 & 11 \\
\hline Mean & & 0.81 & 1.17 & 44.03 & 1.16 & & 0.77 & \\
\hline \multirow[t]{5}{*}{ Low } & IT228277 & 0.24 & 0.34 & 37.52 & 0.25 & 0.0173 & 0.48 & 3 \\
\hline & IT228577 & 0.25 & 0.18 & 22.18 & 0.02 & 0.82 & 0.01 & 2 \\
\hline & IT228620 & 0.35 & 0.19 & 14.81 & 0.00 & 0.9641 & 0.00 & 1 \\
\hline & IT229949 & 0.41 & 0.58 & 30.30 & 0.35 & 0.0036 & 0.63 & 5 \\
\hline & IT230194 & 0.41 & 0.39 & 35.00 & 0.32 & 0.0372 & 0.44 & 6 \\
\hline Mean & & 0.33 & 0.34 & 27.96 & 0.19 & & 0.31 & \\
\hline \multirow[t]{2}{*}{ Check } & Pungsannamul & 0.64 & 0.57 & 23.64 & 0.49 & 0.0001 & 0.88 & 4 \\
\hline & Williams 82 & 0.50 & 0.82 & 34.27 & 0.31 & 0.1181 & 0.22 & 7 \\
\hline $\operatorname{LSD}_{0.05}{ }^{\mathrm{x})}$ & & 0.18 & 0.24 & 11.46 & 0.41 & & 0.29 & \\
\hline
\end{tabular}

${ }^{2)} b_{E}$ was calculated from the regression of mean seed starch content of genotypes at each environments regressed on the environmental index.

${ }^{\mathrm{y})}$ Mean rank was calculated as the average value of three stability parameters range, $\mathrm{CV}$, and $\mathrm{b}_{\mathrm{E}}$.

${ }^{\mathrm{x})}$ LSD for comparison of means of each starch group.

Table 5. Correlation among seed starch (SS), crude fat (CF), and crude protein (CP) contents of 17 soybean genotypes grown at two planting dates at three locations over two years (2015 and 2016).

\begin{tabular}{cccc}
\hline \hline Trait & \multicolumn{1}{c}{ SS } & CF & CP \\
\hline SS & 1 & & \\
CF & $0.1295^{*}$ & 1 & \\
CP & $-0.63^{* * * *}$ & $-0.391^{* * * *}$ & 1 \\
\hline
\end{tabular}

* and **** significant at the 0.05 and 0.0001 probability level, respectively.

\section{DISCUSSION}

Evaluating genotypes at different planting dates is important to understand the variation in SSC during pod-filling at different temperatures (Bilyeu and Wiebold 2016). In order to better understand the stability of SSC across environments, data from the two planting dates of about a month apart, three locations, and two years were utilized in this study. The significant $\mathrm{G} \times \mathrm{E}$ interactions for SSC observed in this study may be due to the differences in genotypes and the growing environments as observed for other carbohydrates components in soybean (Kumar et al. 2010; Bilyeu and Wiebold 2016).

The SSC over two years was significantly different $(P<$ $0.0001)$ which could likely be due to the discrepancies in average daily weather conditions during the pod-filling stage in September and October (Supplementary Table S2). Significant negative correlations between SSC and weather parameters such as average daily mean temperature $\left(P<0.0001, r^{2}=-0.92376\right)$, average daily minimum 
Table 6. Correlation of seed starch content with weather parameters during the seed-filling period (September and October).

\begin{tabular}{|c|c|c|c|c|}
\hline & $\begin{array}{l}\text { Average daily mean } \\
\text { temperature }\end{array}$ & $\begin{array}{l}\text { Average daily } \\
\text { maximum temperature }\end{array}$ & $\begin{array}{l}\text { Average daily } \\
\text { minimum temperature }\end{array}$ & $\begin{array}{l}\text { Average daily } \\
\text { cloudiness }\end{array}$ \\
\hline Correlation coefficient & -0.92376 & -0.26284 & -0.91073 & -0.71239 \\
\hline$P$ value & $<.0001$ & 0.4349 & $<.0001$ & 0.0139 \\
\hline
\end{tabular}

temperature $\left(P<0.0001, r^{2}=-0.91073\right)$, and average daily cloudiness $\left(P=0.0139, r^{2}=-0.71239\right)$ were observed (Table 6). Lower SSC observed in 2016 than in 2015 might be due to longer average daily cloudiness as well as higher average daily temperatures. Gong et al. (2014) observed reduced leaf starch content in soybean grown in shade than those grown under the higher light, which might be due to down-regulation of starch biosynthesis-related genes encoding ADP-glucose pyrophosphorylase, granule-bound starch synthase, and starch-branching enzyme. Egli and Bruening (2001) also observed a reduction in SSC in soybeans grown under shade. The average daily mean and average daily minimum temperatures during active seed filling stage were negatively correlated with the SSC in our study, indicating that the higher temperature reduces SSC. These results are in line with previous reports (Piper and Boote 1999; Thomas et al. 2003) in which the starch and soluble sugar contents in soybean seeds were found to decrease with rise in temperature. Similar correlations have been observed in other crops such as rice (Ahmed et al. 2015) and wheat (Rijven 1986; Zhao et al. 2006; Yan et al. 2008; Liu et al. 2011). The reasons for this phenomenon were supposedly the lower activities of starch synthase, ADP-glucose pyrophosphorylase, starch phosphorylase, and soluble starch synthase enzymes involved in sucrose to starch conversion at higher temperatures (Rijven 1986).

In the present study, high SSC was observed in late (Date 2) planted soybeans than the early planted soybeans. Such differences might be observed due to relatively lower average daily temperatures and shorter average daily cloudiness in October than in September at all the three locations in both the years (Supplementary Table S2). The late planted soybeans experienced relatively lower average daily temperatures and longer sunshine duration during the pod-filling stage than the early (Date 1) planting dates. Piper and Boote (1999) suggested that at lower tem- peratures, carbohydrate is not utilized for oil and protein synthesis because of reduced enzymatic activities. Wolf et al. (1982) reported decreased sucrose content with an increase in temperature after the onset of seed development. Similarly, Sato and Ikeda (1979) studied the effect of increasing temperature on soybean seed composition and found that the total carbohydrate concentrations were found to decrease with an increase in temperature. Relatively longer periods of day-light duration during seed-filling of late-planted soybeans might be another reason for high SSC in the present study. Egli and Bruening (2001) reported decreased SSC in soybean under shade condition. Bilyeu and Wiebold (2016) also observed the higher mean carbohydrate content in late-planted soybeans than in early planted soybeans.

The stability parameters range, $\mathrm{CV}$, and $\mathrm{b}_{\mathrm{E}}$ for mean SSC were calculated to evaluate the stability of different genotypes for various starch classes. Lower values of the range, $\mathrm{CV}$, and $\mathrm{b}_{\mathrm{E}}$ for $\mathrm{SSC}$ of soybeans indicate more stable genotypes across environments (Oliva et al. 2006; Lee et al. 2012). Higher $b_{\mathrm{E}}$ value of the genotypes in high and medium starch groups than the low starch group and check genotypes indicated that they were less stable than the latter groups.

Various physiological and biochemical studies in soybean (Heim et al. 1993; Chopra et al. 2005; Saldivar et al. 2011; Vriet et al. 2014) and sorghum (Bhatia and Singh 2002) imply that biosynthesis of starch and sucrose might be governed by similar genetic factors. Hence, correlation studies of CP and CF were carried out in the present study. The correlation analysis revealed that SSC and oil content in soybean seeds were positively correlated with each other, but negatively correlated with protein content. These results are similar to those reported by Hymowitz et al. (1972). In another study, a significant negative correlation of sucrose with protein has been reported in soybean ( $\mathrm{Li}$ et 
al. 2012). A significant positive correlation of soybean carbohydrates was found with oil whereas a significant negative correlation was shown with protein (Sakla et al. 1988). The total sugar and oil contents in soybean seeds were positively correlated with each other but negatively correlated with protein concentration (Openshaw and Hadley 1978). A high negative correlation was observed between the protein and sucrose contents in soybean (Wee et al. 2017). Similarly, in lupin seeds, a negative correlation was reported between CP and starch content (Straková et al. 2006). The negative correlation between protein and fat found in our study is in line with previous reports in soybean (Sakla et al. 1988; Tajuddin et al. 2003; Haghi et al. 2012; Qin et al. 2014).

In summary, the present study showed that the SSC in soybean was highly affected by the genotype, environment, and their interaction. High seed starch soybean genotypes were found to be less stable than the medium or low starch genotypes across environments (temporal and spatial). The SSC was found to negatively correlate with the average daily mean and average daily minimum temperatures and, with the average daily cloudiness during the pod-filling stage. Further, it was also observed that the late-planted soybeans accumulate higher seed starch than the early planted ones. The results also suggest that the environmental conditions like presence of low temperature and long sunshine period during seed filling stage might be favorable for enhancing the SSC in soybean genotypes. The findings from this study provide an insight into the variation and stability of SSC in soybean genotypes evaluated across environments.

\section{ACKNOWLEDGEMENTS}

This work was carried out with the support of "Cooperative Research Program for Agriculture Science and Technology Development (Project No. PJ0129300 12017)" Rural Development Administration, Republic of Korea.

\section{REFERENCES}

AACC. 2010. Approved methods of the American Association of Cereal Chemists. 11th ed. AACC Method 76-13.01, St. Paul, MN.

Ahmed N, Tetlow IJ, Nawaz S, Iqbal A, Mubin M, ul Rehman $\mathrm{N}$, et al. 2015. Effect of high temperature on grain filling period, yield, amylose content and activity of starch biosynthesis enzymes in endosperm of basmati rice. $\mathrm{J}$. Sci. Food Agric. 95: 2237-2243.

Asekova S, Chae JH, Ha BK, Dhakal KH, Chung G, Shannon JG, et al. 2014. Stability of elevated $\alpha$-linolenic acid derived from wild soybean (Glycine soja Sieb. and Zucc.) across environments. Euphytica 195: 409-418.

Asekova S, Kulkarni KP, Kim M, Kim JH, Song JT, Shannon $\mathrm{JG}$, et al. 2016. Novel Quantitative trait loci for forage quality traits in a cross between PI 483463 and 'Hutcheson' in soybean. Crop Sci. 56: 2600-2611.

Bach S, Yada RY, Bizimungu B, Fan M, Sullivan JA. 2013. Genotype by environment interaction effects on starch content and digestibility in potato (Solanum tuberosum L.). J. Agric. Food Chem. 61: 3941-3948.

Bhatia S, Singh R. 2002. Phytohormone-mediated transformation of sugars to starch in relation to the activities of amylases, sucrose-metabolising enzymes in sorghum grain. Plant Growth Regul. 36: 97-104.

Bilyeu KD, Wiebold WJ. 2016. Environmental stability of seed carbohydrate profiles in soybeans containing different alleles of the raffinose synthase 2 (RS2) gene. J. Agric. Food Chem. 64: 1071-1078.

Boonvisut S, Whitaker JR. 1976. Effect of heat, amylase, and disulfide bond cleavage on the in vitro digestibility of soybean proteins. J. Agric. Food Chem. 24: 1130-1135.

Burton JW. 1997. Soyabean (Glycine $\max$ (L.) Merr.). Field Crops Res. 53: 171-186.

Chae JH, Ha BK, Chung G, Park JE, Park E, Ko JM, et al. 2015. Identification of environmentally stable wild soybean genotypes with high alpha-linolenic acid concentration. Crop Sci. 55: 1629-1636.

Choct M. 1997. Feed non-starch polysaccharides: chemical structures and nutritional significance. Feed Milling International 191: 13-26.

Chopra J, Kaur N, Gupta AK. 2005. Role of enzymes of sucrose-starch conversion in seed sink strength in mung bean. Biol. Plant. 49: 561-566. 
Chung MG, Baek IY, Kang ST, Ha WY, Shin DC, Moon HP, et al. 2001. Determination of protein and oil contents in soybean seed by near infrared reflectance spectroscopy. Korean J. Crop Sci. 46: 106-111.

Cicek M. 2001. Genetic marker analysis of three major carbohydrates in soybean seeds. Ph.D. diss., Virginia Polytechnic Institute and State Univ., Blacksburg.

Cober ER, Fregeau-Reid JA, Pietrzak LN, McElroy AR, Voldeng HD. 1997. Genotype and environmental effects on natto soybean quality traits. Crop Sci. 37: 1151-1154.

Dhakal KH, Lee JD, Jeong YS, Kim HS, Shannon JG, Hwang YH. 2013. Stability of linolenic acid in seed oil of soybean accessions with elevated linolenic acid concentration. J. Food Agric. Environ. 11: 80-85.

Dhungana SK, Kulkarni KP, Park CW, Jo H, Song JT, Shin $\mathrm{DH}$, et al. 2017. Mapping quantitative trait loci controlling soybean seed starch content in an interspecific cross of Williams 82 (Glycine max) and PI 366121 (Glycine soja). Plant Breed. 136: 379-385.

Dornbos DL, Mullen RE. 1992. Soybean seed protein and oil contents and fatty acid composition adjustments by drought and temperature. J. Am. Oil Chem. Soc. 69: 228-231.

Egli DB, Bruening WP. 2001. Source-sink relationships, seed sucrose levels and seed growth rates in soybean. Ann. Bot. 88: 235-242.

El-Soda M, Malosetti M, Zwaan BJ, Koornneef M, Aarts MG. 2014. Genotype $\times$ environment interaction QTL mapping in plants: lessons from Arabidopsis. Trends Plant Sci. 19: 390-398.

Fehr WR, Hoeck JA, Johnson SL, Murphy PA, Nott JD, Padilla GI, et al. 2003. Genotype and environment influence on protein components of soybean. Crop Sci. 43: 511-514.

Geater CW, Fehr WR. 2000. Association of total sugar content with other seed traits of diverse soybean cultivars. Crop Sci. 40: 1552-1555.

Gong W, Qi P, Du J, Sun X, Wu X, Song C, et al. 2014. Transcriptome analysis of shade-induced inhibition on leaf size in relay intercropped soybean. PLoS ONE 9: e98465.

Greiner C. 1990. Economic implication of modified soybean trait. Iowa soybean promotion board, Iowa agricultural and home economics experiment station, Iowa state University, Ames, IA.
Haghi Y, Boroomandan P, Moradin M, Hassankhali M, Farhadi P, Farsaei F, et al. 2012. Correlation and path analysis for yield, oil and protein content of Soybean (Glycine $\max$ L.) genotypes under different levels of nitrogen starter and plant density. Biharean Biologist 6 : 32-37.

Heim U, Weber H, Bäumlein H, Wobus U. 1993. A sucrosesynthase gene of Vicia faba L.: expression pattern in developing seeds in relation to starch synthesis and metabolic regulation. Planta 191: 394-401.

Hou G, Ablett GR, Pauls KP, Rajcan I. 2006. Environmental effects on fatty acid levels in soybean seed oil. J. Am. Oil Chem. Soc. 83: 759-763.

Hymowitz T, Collins FI, Panczner J, Walker WM. 1972. Relationship between the content of oil, protein, and sugar in soybean seed. Agron. J. 64: 613-616.

Jeong WH, Harada K, Yamada T, Abe J, Kitamura K. 2010. Establishment of new method for analysis of starch contents and varietal differences in soybean seeds. Breed. Sci. 60: 160-163.

Koo SC, Jeon MG, Lee YH, Kim HY, Kang BK, Go JM, et al. 2014. Screening of soybean germplasm with high starch content. Korean J. Breed. Sci. 46: 52-57.

Kulkarni KP, Asekova S, Lee DH, Bilyeu K, Song JT, Lee JD. 2017. Mapping QTLs for 100-seed weight in an interspecific soybean cross of Williams 82 (Glycine max) and PI 366121 (Glycine soja). Crop Pasture Sci. 68: 148-155.

Kulkarni KP, Kim M, Shannon JG, Lee JD. 2016. Identification of quantitative trait loci controlling soybean seed weight in recombinant inbred lines derived from PI 483463 (Glycine soja) × 'Hutcheson' (G. max). Plant Breed. 135: 614-620.

Kumar V, Rani A, Goyal L, Dixit AK, Manjaya JG, Dev J, et al. 2010. Sucrose and raffinose family oligosaccharides (RFOs) in soybean seeds as influenced by genotype and growing location. J. Agric. Food Chem. 58: 5081-5085.

Lee JD, Bilyeu KD, Pantalone VR, Gillen AM, So YS, Shannon JG. 2012. Environmental stability of oleic acid concentration in seed oil for soybean lines with and mutant genes. Crop Sci. 52: 1290-1297.

Lee JD, Woolard M, Sleper DA, Smith JR, Pantalone VR, Nyinyi CN, et al. 2009. Environmental effects on oleic acid in soybean seed oil of plant introductions with elevated oleic concentration. Crop Sci. 49: 1762-1768. 
Li YS, Du M, Zhang QY, Wang GH, Hashemi M, Liu XB. 2012. Greater differences exist in seed protein, oil, total soluble sugar and sucrose content of vegetable soybean genotypes [Glycine max (L.) Merrill] in Northeast China. Aust. J. Crop Sci. 6: 1681-1686.

Liu K. 1997. Chemistry and nutritional value of soybean components, p. 25-113. In: K. Liu (ed.). Soybeans. Springer, Boston, MA.

Liu P, Guo W, Jiang Z, Pu H, Feng C, Zhu X, et al. 2011. Effects of high temperature after anthesis on starch granules in grains of wheat (Triticum aestivum L.). J. Agric. Sci. 149: 159-169.

Masuda R. 2004. Elucidation of the maltose production on improvement of the eating quality of green soybean. Agri. Hort. 79: 1085-1093.

Mtunguja MK, Laswai HS, Kanju E, Ndunguru J, Muzanila YC. 2016. Effect of genotype and genotype by environment interaction on total cyanide content, fresh root, and starch yield in farmer-preferred cassava landraces in Tanzania. Food Sci. Nutr. 4: 791-801.

Oliva ML, Shannon JG, Sleper DA, Ellersieck MR, Cardinal AJ, Paris RL, et al. 2006. Stability of fatty acid profile in soybean genotypes with modified seed oil composition. Crop Sci. 46: 2069-2075.

Openshaw SJ, Hadley HH. 1978. Maternal effects on sugar content in soybean seeds. Crop Sci. 18: 581-584.

Panthee DR, Pantalone VR, West DR, Saxton AM, Sams CE. 2005. Quantitative trait loci for seed protein and oil concentration, and seed size in soybean. Crop Sci. 45: 2015-2022.

Patil, G., Mian, R., Vuong, T., Pantalone, V., Song, Q., Chen, $\mathrm{P}$, et al. 2017. Molecular mapping and genomics of soybean seed protein: a review and perspective for the future. Theor. Appl. Genet. 130: 1975-1991.

Piper EL, Boote KI. 1999. Temperature and cultivar effects on soybean seed oil and protein concentrations. J. Am. Oil Chem. Soc. 76: 1233-1241.

Primomo VS, Falk DE, Ablett GR, Tanner JW, Rajcan I. 2002. Genotype $\times$ environment interactions, stability, and agronomic performance of soybean with altered fatty acid profiles. Crop Sci. 42: 37-44.

Primomo VS, Poysa V, Ablett GR, Jackson CJ, Gijzen M, Rajcan I. 2005. Mapping QTL for individual and total isoflavone content in soybean seeds. Crop Sci. 45: 24542464.
Qin P, Song W, Yang X, Sun S, Zhou X, Yang R, et al. 2014. Regional distribution of protein and oil compositions of soybean cultivars in China. Crop Sci. 54: 1139-1146.

Rao MS, Mullinix BG, Rangappa M, Cebert E, Bhagsari AS, Sapra VT, et al. 2002. Genotype $\times$ environment interactions and yield stability of food-grade soybean genotypes. Agron. J. 94: 72-80.

Rennie BD, Tanner JW. 1989. Fatty acid composition of oil from soybean seeds grown at extreme temperatures. J. Am. Oil Chem. Soc. 66: 1622-1624.

Rijven AHGC. 1986. Heat inactivation of starch synthase in wheat endosperm tissue. Plant Physiol. 81: 448-453.

Sakla AB, Ghali Y, El-Farra A, Rizk LF. 1988. The effect of environmental conditions on the chemical composition of soybean seeds: Relationship between the protein, oil, carbohydrate and trypsin inhibitor content. Food Chem. 29: 221-231.

Saldivar X, Wang YJ, Chen P, Hou A. 2011. Changes in chemical composition during soybean seed development. Food Chem. 124: 1369-1375.

SAS Institute. 2013. Base SAS 9.4 Procedures Guide. SAS Inst., Cary, NC.

Sato K, Ikeda T. 1979. The growth responses of soybean plant to photoperiod and temperature IV. The effect of temperature during the ripening period on the yield and character of seeds. Jpn. J. Crop Sci. 48: 283-290.

Shen X, Zhang T, Guo W, Zhu X, Zhang X. 2006. Mapping fiber and yield QTLs with main, epistatic, and QTL× environment interaction effects in recombinant inbred lines of upland cotton. Crop Sci. 46: 61-66.

Sivapragasam N, Thavarajah P, Ohm JB, Margaret K. 2014. Novel starch based nano scale enteric coatings from soybean meal for colon-specific delivery. Carbohydr. Polym. 111: 273-279.

Stevenson DG, Doorenbos RK, Jane JL, Inglett GE. 2006. Structures and functional properties of starch from seeds of three soybean (Glycine max (L.) Merr.) varieties. Starch-Stärke 58: 509-519.

Straková E, Suchý P, Večerek V, Šerman V, Mas N, Jůzl M. 2006. Nutritional composition of seeds of the genus Lupinus. Acta Vet. Brno. 75: 489-493.

Suh S, Kim H, Oh Y, Kim K, Cho S, Kim Y, et al. 1997. A new soybean variety for sprout with small seed and high yielding 'Pungsannamulkong'. Korean J. Breed. Sci. 29: 503. 
Tajuddin T, Watanabe S, Yamanaka N, Harada K. 2003. Analysis of quantitative trait loci for protein and lipid contents in soybean seeds using recombinant inbred lines. Breed. Sci. 53: 133-140.

Thomas JM, Boote KJ, Allen LH, Gallo-Meagher M, Davis JM. 2003. Elevated temperature and carbon dioxide effects on soybean seed composition and transcript abundance. Crop Sci. 43: 1548-1557.

Toker C. 2004. Estimates of broad-sense heritability for seed yield and yield criteria in faba bean (Vicia faba L.). Hereditas 140: 222-225.

Vriet C, Edwards A, Smith AM, Wang TL. 2014. Sucrose and starch metabolism, p. 97-115. In: S. Tabata, J. Stougaard (eds.). The Lotus japonicus Genome. Springer-Verlag, Heidelberg, Berlin.

Wee CD, Hashiguchi M, Ishigaki G, Muguerza M, Oba C, Abe J, et al. 2017. Evaluation of seed components of wild soybean (Glycine soja) collected in Japan using nearinfrared reflectance spectroscopy. Plant Genet. Resour.
$1-9$.

Wilson LA, Birmingham VA, Moon DP, Snyder HE. 1978. Isolation and characterization of starch from mature soybeans. Cereal Chem. 55: 661-670.

Wolf RB, Cavins JF, Kleiman R, Black LT. 1982. Effect of temperature on soybean seed constituents: Oil, protein, moisture, fatty acids, amino acids and sugars. J. Am. Oil Chem. Soc. 59: 230-232.

Yan SH, Yin YP, Li WY, Liang TB, Li Y, Wu YH, et al. 2008. Effect of high temperature during grain filling on starch accumulation, starch granule distribution, and activities of related enzymes in wheat grains. Acta Agron. Sin. 34: 1092-1096.

Zhao H, Dai TB, Jing Q, Jiang D, Cao WX, Lu W, et al. 2006. Effects of high temperature during grain filling on key enzymes involved in starch synthesis in two wheat cultivars with different quality types. Acta Agron. Sin. 32: 423-429. 